\title{
ANALISA STRATEGI BERSAING PT. GARUDA INDONESIA TBK. (PERSERO)
}

\author{
Rosa Lesmana*) \& Novia Susanti $\left.{ }^{\star *}\right)$ \\ email :dosen01360@unpam.ac.id
}

\begin{abstract}
ABSTRAK
Tujuan dari penelitian ini adalah untuk mengetahui strategi bersaing dan daya saing PT. Garuda Indonesia Tbk. (Persero) saat ini dan masa akan datang. Penelitian ini menggunakan metode kualitatif. Data dikumpulkan melalui observasi, dokumentasi dan wawancara kepada pihak PT. Garuda Indonesia Tbk. (Persero) maupun kepada konsumen. Analisis SWOT dengan analisa matrik internal dan eksternal digunakan dalam penelitian ini. Hasil penelitian secara internal menunjukkan bahwa PT. Garuda Indonesia Tbk. (Persero) memiliki Kekuatan utama dan seccara Eksternal memiliki Peluang yang besar. Sedangkan posisi perusahaan berada pada Startegi Pertumbuhan dengan Diversifikasi (sel 1). Dimana strategi yang dapat dilakukan adalah dengan cara menambah jumlah penerbangan, rute, armada dan mengembangkan bisnis baru baik yang terkait dengan bisnis penerbangan maupun tidak terkait bisnis penerbangan. guna meminimalisir kelemahan PT. Garuda Indonesia Tbk. (Persero). Sehingga PT. Garuda Indonesia Tbk. (Persero) tetap akan menunjukkan keunggulan kompetitifnya.
\end{abstract}

Kata Kunci : Analisis SWOT, Strategi Bersaing

ABSTRACT

The purpose of this research is to know competitive strategy and competitiveness of PT. Garuda Indonesia Tbk. (Persero) the current and future competition. This research study with qualitative methods. Data were collected through observation, documentation and interviews to the customer of PT. Garuda Indonesia Tbk. (Persero). This study using the SWOT analysis with internal and eksternal matriks. Based on Internal and eksternal Assesment PT. Garuda Indonesia Tbk. (Persero) is in good strength and big opportunity. While company strategy position is in Growth with diversification strategy. (sel 1) it's means the suitable strategy to be implemented is adding the new rute, new armada and create new bussiness line of PT. Garuda Indonesia Tbk.

Keywords : SWOT Analysis, Competitive Advantage

\section{A. Pendahuluan}

Persaingan yang begitu ketat menuntut setiap maskapai harus bekerja keras lagi untuk turut serta dalam persaingan tersebut. Tantangan yang dihadapi oleh perusahaan yang bersaing diantaranya adalah selalu mendapatkan cara terbaik untuk merebut dan mempertahankan pangsa pasar. Maka dari itu, setiap pelaku usaha harus bisa menyusun dan mendesain suatu strategi yang nantinya mampu mendukung usahanya.

Bagi PT. Garuda Indonesia Tbk (Persero), prospek usaha pada bisnis penerbangan yang dihadapi saat ini dan masa yang akan datang, mempunyai potensi yang besar untuk berkembang. Pasar yang ada di berbagai kawasan masih 
dapat ditumbuh kembangkan lebih lanjut, diperkirakan pasar Garuda Indonesia tumbuh sebesar kurang-lebih $5.7 \%$ pertahun.

Saat ini Garuda Indonesia mengoperasikan 185 armada untuk melayani 160 rute domestik dan 25 rute internasional termasuk Asia (Regional Asia Tenggara, Timur Tengah, China, Jepang, dan Korea Selatan, Australia serta Eropa (Belanda).

Namun peningkatan jumlah penumpang PT. Garuda Indonesia Tbk (Persero) dari tahun 2012-2016 relatif masih sangat kecil.

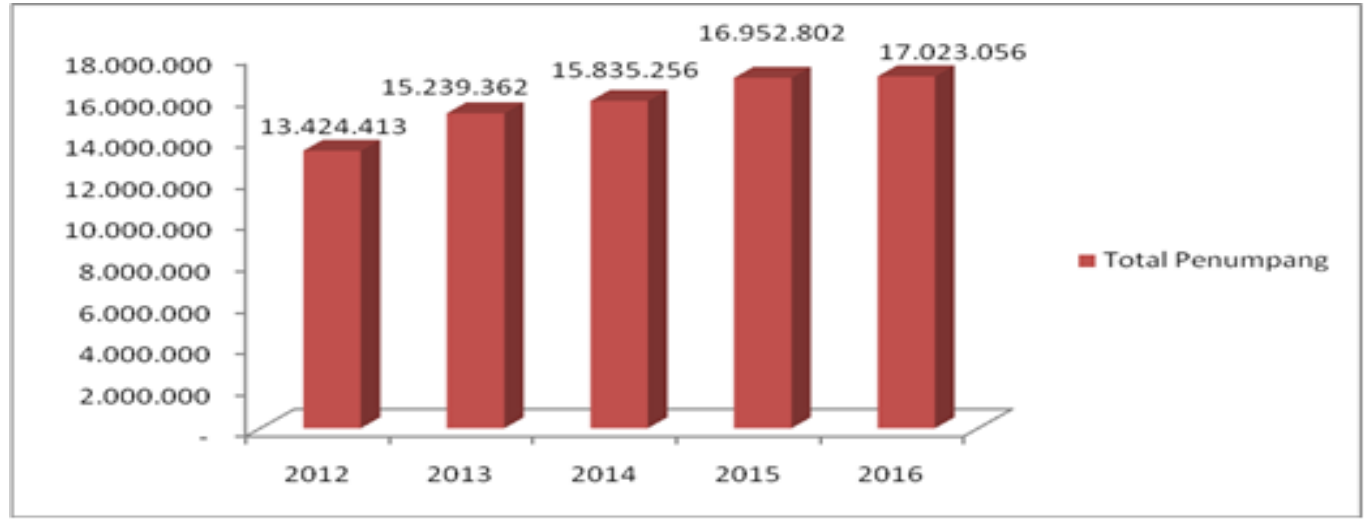

Gambar 1.1 : Pertumbhan Jumlah Penumpang

Strategi dirumuskan sebagai suatu pernyataan yang mengarahkan bagaimana masing-masing individu dapat bekerjasama dalam suatu organisasi, dalam pencapaian tujuan dan sasaran organisasi (Sofjan Assauri, 2013).

Unsur-unsur strategi menurut Sofjan Assauri (2013) adalah sebagai berikut: (1) gelanggang aktifitas atau arena dimana organisasi beroperasi ; (2) sarana kendaraan atau vehicle yang digunakan unruk dapat mencapai arena sasaran; (3) Pembeda yang dibuat atau differentiators; (4) Tahapan rencana yang dilalui atau staging, yang merupakan penetapan waktu dan langakah dari pergerakan dari suatu strategi atau strategic moves; dan (5) Pemikiran yang ekonomis atau ekonomic logic, merupakan gagasan yang jelas tentang bagaimana manfaat atau keuntungan yang akan dihasilkan.

Organisasi tidak akan mencapai keunggulan bersaing berkelanjutan jika hanya mengikuti product market based strategy atau resource based strategy saja. Sumber daya pengetahuan memberikan basis yang kuat bagi perusahaan untuk menciptakan keunggulan bersaing berkelanjutan. Untuk megembangkan pengetahuan berbasis strategi dalam rangka penciptaan keunggulan bersaing yang berkelnjutan diperlukan upaya yang berkesinambungan, membutuhkan pemahaman kedepan serta 
perencanaan yang komprehensif. Keunggulan kompetitif menurut Warren J. Keegan (2007) merupakan konsep dasar pemasaran yang kedua. Sedangkan yang pertama adalah nelai pelanggan dan persamaan nilai.

Adapun pengertian pemasaran yang dikemukakan oleh Philip Kotler (2013): "Marketing is sociental process by which individuals and groups obtain what they need and want trought creating, offering, and freely exchanging product and service of value with other". Pengertian diatas dapat diartikan sebagai: "Pemasaran adalah suatu proses sosial yang di dalamnya individu dan kelompok mendapatkan apa yang mereka butuhkan dan inginkan dengan menciptakan, menawarkan, dan secara bebas mempertukarkan produk yang paling bernilai dengan pihak lain".

Sedangkan menurut Handoko (2013), yang dimaksud dengan perencanaan strategi adalah suatu proses pengalihan tujuan-tujuan organisasi, penentuan strategi,kebijaksanaan dari program-program strategi yang diperlukan untuk tujuantujuan tersebut, dan penetapan metode-metode yang diperlukan untuk menjamin bahwa strategi dan kebijaksanaan telah diimplementasikan. Menurut Kotler dan Keller (2013) menjelaskan bahwa langkah-langkah dalam perencanaan strategi bisnis dapat dilihat seperti pada gambar dibawah ini :

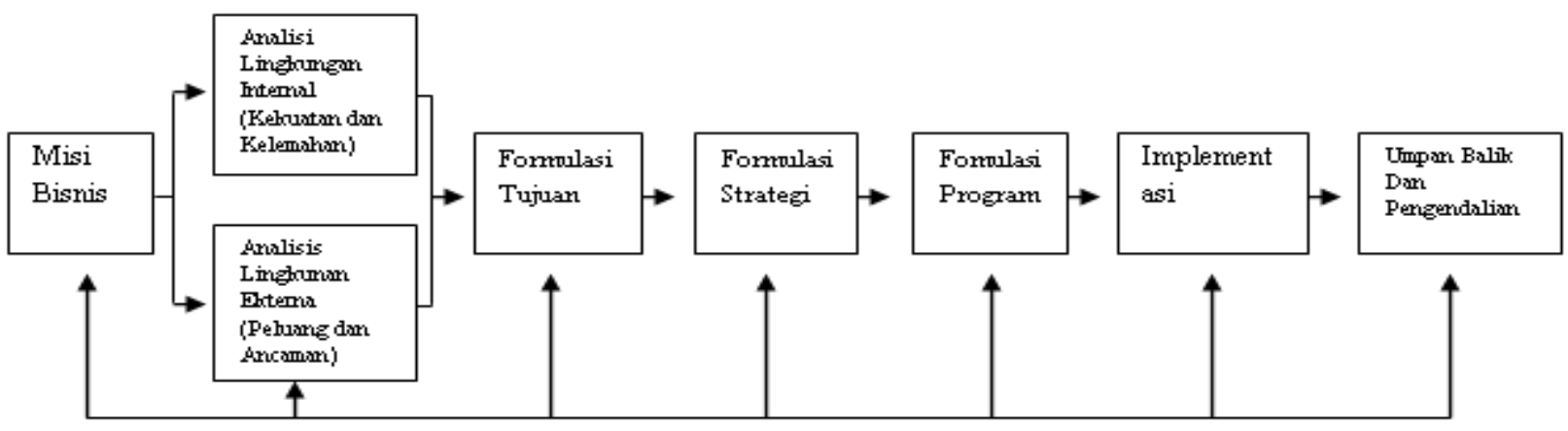

\section{Gambar 1.2 : Pertumbhan Jumlah Penumpang}

Tujuan dari penelitian ini adalah untuk mengetahui strategi bersaing dan keunggulan bersaing PT. Garuda Indonesia Tbk (Persero) saat ini dan masa yang akan datang.

\section{B. METODE PENELITIAN}

Lokasi penelitian di PT. Garuda Indonesia Airlines yang berlokasi di Bandara Soekarno Hatta Internasional Terminal 3 Ultimate Tangerang Banten Telp (02125601950). Pendekatan yang digunakan dalam penelitian ini adalah pendekatan kualitatif, yakni memahami suatu fenomena yang dialami oleh subyek penelitian. 
Sebagaimana Moleong (2006) penelitian kualitatif dimaksudkan untuk memahami fenomena yang dialami oleh subyek penelitian missal persepsi, prilaku, motivasi, tindakan, dengan konteks khusus alamiah serta memanfaatkan berbagai metode ilmiah.

Analisis SWOT (Strenghts, Weaknesses, Opportunities, dan Threats) adalah analisis yang dilakukan terhadap keadaan atau faktor internal perusahaan (kekuatan dan kelemahan) dan faktor eksternal perusahaan (peluang dan anacaman) yang dapat mempengaruhi operasi perusahaan.

Dengan mengetahui basil analisis ini diharapkan perusahaan dapat menggunakan seluruh kekuatan, memanfaatkan peluang yang ada untuk mengatasi kelemahan dan ancaman yang dihadapi perusahaan. Dari hasil analisis SWOT dapat dipergunakan untuk mengetahui posisi perusahaan dan menentukan strategi pemasaran perusahaan.

Semua variabel dalam penelitian ini dapat membantu dalam melakukan formulasi strategi. Matrik IE membantu dalam hal analisis lebih lanjut. Sebelum membuat matrik IE, terlebih dahulu dilakukan analisis SWOT yang hasilnya dirangkum dalam tabel EFAS dan IFAS. Penerapan analisis SWOT dilakukan dengan mempertimbangkan kekuatan (strength) dan kelemahan (weakness) sebagai faktor internal serta peluang (opportunity) dan ancaman (threat) sebagai faktor eksternal yang dimiliki oleh PT. Garuda Indonesia Tbk (Persero).

Tabel 3.1: Kriteria Penilaian Hasil Analisis

\begin{tabular}{|c|c|l|l|}
\hline Nilai & Rentang & \multicolumn{1}{|c|}{ Hasil Internal } & \multicolumn{1}{|c|}{ Hasil Eksternal } \\
\hline 1 & $1,00-1,80$ & Kelemahan utama & Ancaman besar \\
2 & $1,81-2,60$ & Kelemahan kecil & Ancaman kecil \\
3 & $2,61-3,40$ & Kekuatan sedang & Ancaman sedang \\
4 & $3,41-4,20$ & Kekuatan kecil & Peluang besar \\
5 & $4,21-5,00$ & Kekuatan utama & Peluang kecil \\
\hline
\end{tabular}

Sumber : Duarta (2008: 79)

a. Strategi Pertumbuhan (Growth Strategy), yang merupakan pertumbuhan perusahaan itu sendiri (sel 1, 2, 5), dan pertumbuhan dengan upaya diversifikasi (sel 7 dan 8).

b. Strategi Stabilitas (Stability Strategy), (sel 4) yaitu Strategi yang diterapkan tanpa mengubah arah strategi yang telah ditetapkan. 
c. Strategi Penciutan (Retrenchment Strategy), (sel 3, 6, 9) adalah usaha memperkecil atau mengurangi usaha yang dilakukan perusahaan.

\begin{tabular}{|c|c|c|c|}
\hline 4 & $\begin{array}{l}\text { Kuat } \\
3,41-5,00 \\
3\end{array}$ & $\begin{array}{l}\text { Sedang } \\
2,61-3,40 \\
2\end{array}$ & $\begin{array}{l}\text { Lemah } \\
1,00-2,60 \\
1\end{array}$ \\
\hline $\begin{array}{l}\text { Tinggi } \\
3,41- \\
5,00 \\
3\end{array}$ & $\begin{array}{l}1 \\
\text { Pertumbuhan } \\
\text { (growth), }\end{array}$ & $\begin{array}{l}2 \\
\text { Pertumbuhan } \\
\text { (growth), }\end{array}$ & $\begin{array}{l}3 \\
\text { Penciutan } \\
\text { Turn Around }\end{array}$ \\
\hline $\begin{array}{l}\text { Sedang } \\
2,61- \\
3,40 \\
2\end{array}$ & $\begin{array}{l} \\
\text { Stabilitas } \\
\text { Hati-hati }\end{array}$ & $\begin{array}{l}5 \\
\text { Pertumbuhan } \\
\text { Konsentrasi } \\
\text { via Integrasi } \\
\text { Horizontal }\end{array}$ & $\begin{array}{l}6 \\
\text { Penciutan } \\
\text { Divestment }\end{array}$ \\
\hline $\begin{array}{l}\text { Rendah } \\
1,00- \\
2,60 \\
1\end{array}$ & $\begin{array}{l}7 \\
\text { Pertumbuhan } \\
\text { (growth) } \\
\text { Diversifikasi }\end{array}$ & $\begin{array}{l}8 \\
\text { Pertumbuhan } \\
\text { (growth) } \\
\text { Diversifikasi }\end{array}$ & $\begin{array}{l}9 \\
\text { Likuidasi } \\
\text { Bangkrut/Likuidasi }\end{array}$ \\
\hline
\end{tabular}

Sumber: Rangkuti (2006: 42)

Gambar 3.1 Matriks Internal Eksternal (IE)

\section{HASIL DAN PEMBAHASAN}

Data Umum Lokasi Penelitian, PT. Garuda Indonesia Tbk (Persero) yang berlokasi di Bandara Soekarno Hatta Internasional Terminal 3 Ultimate Tangerang Banten Telp (021-25601950). Penerbangan komersial pertama menggunakan pesawat DC-3 Dakota dengan registrasi RI 001 dari Calcutta ke Rangoon dan diberi nama "Indonesia Airways" dilakukan pada 26 januari 1949. Pada tahun yang sama, 28 Desember 1949, pesawat tipe Douglas DC-3 Dakotadengan registrasi PK-DPD dan sudah dicat dengan logo "Garuda Indonesia Airways", terbang dari Jakarta ke Yogyakarta untuk menjemput Presiden Soekarno. Inilah penerbangan yang pertama kali dengan nama Garuda Indonesia Airways. Nama "Garuda" diberikan oleh Presiden Soekarno dimana nama tersebut diambil dari sajak Belanda yang ditulis oleh penyair terkenal pada masa itu, Noto Soeroto "Ik ben Garuda, Vishnoe's vogel, die zijn vleugels uitslaat hoog bovine uw einladen", yang artinya, "Saya Garuda, burung Vishnu yang melebarkan sayapnya tinggi di atas kepulauan Anda".

Pada bulan Juli 2012, GARUDA Indonesia menandatangani perjanjian sponsorship selama 3 tahun dengan klub Liga Inggris Liverpool FC. Persetujuan tersebut membaeri Garuda hak sebagai Official Partner Liverpool Football Club (Mitra 
Resmi Liverpool FC) dan Official Global Airline Partner of Liverpool Football Club ( Mitra Maskapai Penerbangan Global Resmi Liverpool FC).

Pada tahun 2017 Garuda Indonesia-maskapai pembawa bendera Bangsa saat ini tercatat melayani 83 destinasi di seluruh dunia dan berbagai lokasi eksotis di Indonesia. Dengan jumlag penerbangan lebih dari 600 penerbangan per hari dan jumlah armada 196 pesawat di januari 2017, Garuda Indonesia memberikan pelayanan baik melalui konsep "Garuda Indonesia Experience" yang mengedepankan keramahtamahan dan kekayaan budaya Indonesia. Garuda Indonesia terus melaksanakan program transformasi secara berkelanjutan. Hasilnya, kini Garuda Indonesia merupakan maskapai bintang lima, dengan berbagai pengakuan dan apresiasi berskala internasional, diantaranya pencapaian "The World's Best Cabin Crew" selama empat tahun berturut-turut, dari tahun 2014 hingga 2017 "World's Most Loved Airline 2016" dan "The World's Best Economy Class 2013" dan Skytrax, lembaga pemeringkat penerbangan independen berbasis di London.

\section{Analisis IFAS dan EFAS}

Dari table kekuatan dan kelemahan dapat dibuat analisis IFAS seperti disajikan pada table 3 dan dari table peluang dan ancaman dapat dianalisis EFAS seperti pada table 4.1

Tabel 4.1 : INTERNAL FACTOR ANALYSIS SUMMARY (IFAS)

\begin{tabular}{lll}
\hline Indikator Kekuatan(Strength) & Bobot & Skor \\
\hline Fasilitas yang baik dan nyaman, & 4,57 & 0,45 \\
$\begin{array}{l}\text { Terjaganya kebersihan dan } \\
\text { keamanan dalam penerbangan }\end{array}$ & 4,71 & 0,48 \\
$\begin{array}{l}\text { SDM(Pilot,pramugari,karyawan) } \\
\text { memiliki daya tanggap tinggi }\end{array}$ & 4,71 & 0,48 \\
$\begin{array}{l}\text { SDM(Pilot,pramugari,karyawan) } \\
\text { memiliki rasa kepedulian tinggi }\end{array}$ & 4,43 & 0,42 \\
SDM(Pilot,pramugari,karyawan) & 4,71 & 0,48 \\
yang handal & 23,14 & $\mathbf{2 , 3 0}$ \\
SubTotal 1 & Bobot & Skor \\
\hline Indikator Kelemahan(weakness) & 4,86 & 0,51 \\
\hline Citra ekslusif & 5,00 & 0,54 \\
Promo khusus kurang & 5,00 & 0,54 \\
Harga tidak terjangkau semua & 4,00 & 0,34 \\
kalangan & 4,57 & 0,45 \\
Seknologi kurang canggih & 23,43 & $\mathbf{2 , 3 7}$ \\
masialisasi dan promos kepada & & $\mathbf{4 , 6 7}$ \\
SubTotal 2 & & \\
Grand Total & &
\end{tabular}

Sumber: Data diolah peneliti 
Dari hasil skor analisis SWOT strategi bersaing PT. Garuda Indonesia Tbk (Persero) dapat diketahui bahwa aspek internal (IFAS) untuk indikator kekuatan (Strength) 2,30 dengan rincian terdiri dari beberapa indikator yaitu Fasilitas yang baik dan nyaman $(0,45)$, Terjaganya kebersihan dan keamanan dalam penerbangan $(0,48)$ SDM(Pilot,pramugari,karyawan) memiliki daya tanggap tinggi $(0,48)$, SDM(Pilot,pramugari,karyawan) memiliki rasa kepedulian tinggi $(0,42)$, SDM(Pilot,pramugari,karyawan) yang handal $(0,48)$ Sedangkan dari indikator Kelemahan (Weakness) yaitu 2,37 dengan rincian terdiri dari beberapa indikator yaitu Citra ekslusif $(0,51)$, Promo khusus kurang $(0,54)$, Harga tidak terjangkau semua kalangan $(0,54)$, Teknologi kurang canggih $(0,34)$, Sosialisasi dan promosi kepada masyarakat masih kurang $(0,45)$. Dan dari hasil Aspek Internal (IFAS) dengan rincian yaitu indikator Kekuatan (Strength) yaitu 2,30 dan Kelemahan (Weakness) 2,37. Dari hasil analisa tersebut, maka dapat dilihat pada tabel Kriteria Penilaian Hasil Analisis berada pada rentang 4,21- 5,00 dimana PT. Garuda Indonesia Tbk (Persero) memiliki Kekuatan Utama.

Tabel 2. EKSTERNAL FACTOR ANALYSIS SUMMARY (EFAS)

\begin{tabular}{|c|c|c|}
\hline Indikator Peluang (Opportunity) & Bobot & Skor \\
\hline Kebijakan pemerintah & 3,71 & 0,45 \\
\hline Nilai tukar rupiah stabil & 3,71 & 0,45 \\
\hline Mengikuti perkembangan teknologi & 4.43 & 0,64 \\
\hline Budaya Masyarakat & 3,71 & 0,45 \\
\hline Sub Total & & 2,00 \\
\hline Indikator Ancaman (Threat) & Bobot & Skor \\
\hline Kompetitor dengan modal besar & 4,57 & 0,69 \\
\hline Stabilitas Ekonomi Indonesia & 3,86 & 0,49 \\
\hline Tingkat Inflasi Tinggi & 3,86 & 0,49 \\
\hline Peningkatan Pendapatan masyarakat masih rendah & 2,57 & 0,22 \\
\hline Sub Total 2 & & 1,88 \\
\hline Grand Total & & 3,88 \\
\hline
\end{tabular}

Sumber: Data diolah peneliti

Berdasarkan dari hasil skoring analisa SWOT, maka strategi bersaing PT. Garuda Indonesia Tbk (Persero), dapat diketahui bahwa aspek eskternal (EFAS) untuk indikator peluang (Opportunity) yaitu mendapatkan total skor 2,00 dengan rincian yang terdiri dari beberapa indikator yaitu Kebijakan pemerintah $(0,45)$ Nilai 
tukar rupiah stabil $(0,45)$, mengikuti perkembangan teknologi $(0,64)$, Budaya Masyarakat $(0,45)$.

Sedangkan dari indikator Ancaman (Threat) mendapat total skor 1,88 dengan rincian terdiri dari beberapa indikator yaitu kompetitor dengan modal besar $(0,69)$, stabilitas ekonomi Indonesia masih rendah $(0,49)$, Tingkat inflasi tinggi $(0,49)$, Pendapatan masyarakat rendah $(0,22)$. Jadi, hasil dari aspek eksternal (EFAS) dengan rincian yaitu indikator Peluang (Opportunity) yaitu 2,00 dan Ancaman (Threat) sebesar 1,88 Dari hasil analisa tersebut, maka dapat dilihat pada tabel Kriteria Penilaian Hasil Analisis berada pada rentang 3,41- 4,20 dimana PT. Garuda Indonesia Tbk (Persero) memiliki Peluang Besar.

\begin{tabular}{|c|c|c|c|}
\hline 4 & $\begin{array}{l}\text { Kuat } \\
3,41-5,00 \\
3\end{array}$ & $\begin{array}{l}\text { Sedang } \\
2,61-3,40 \\
2\end{array}$ & $\begin{array}{l}\text { Lemah } \\
1,00-2,60 \\
1\end{array}$ \\
\hline $\begin{array}{l}\text { Tinggi } \\
3,41-5,00 \\
3\end{array}$ & $\frac{1}{\text { Pertumr }}$ & $\begin{array}{l}2 \\
\text { Pertumbuhan } \\
\text { (growth), }\end{array}$ & $\begin{array}{l}3 \\
\text { Penciutan } \\
\text { Turn Around }\end{array}$ \\
\hline $\begin{array}{l}\text { Sedang } \\
2,61-3,40 \\
2\end{array}$ & $\begin{array}{l} \\
\text { Stabilitas } \\
\text { Hati-hati }\end{array}$ & $\begin{array}{l}5 \\
\text { Pertumbuhan } \\
\text { Konsentrasi via } \\
\text { Integrasi } \\
\text { Horizontal }\end{array}$ & $\begin{array}{l}6 \\
\text { Penciutan } \\
\text { Divestment }\end{array}$ \\
\hline $\begin{array}{l}\text { Rendah } \\
1,00-2,60 \\
1\end{array}$ & $\begin{array}{l}7 \\
\text { Pertumbuhan } \\
\text { (growth) } \\
\text { Diversifikasi }\end{array}$ & $\begin{array}{l}8 \\
\text { Pertumbuhan } \\
\text { (growth) } \\
\text { Diversifikasi }\end{array}$ & $\begin{array}{l}9 \\
\text { Likuidasi } \\
\text { Bangkrut/Likuidasi }\end{array}$ \\
\hline
\end{tabular}

Gambar 4.1 Matriks Internal Eksternal (IE)

Strategi Bersaing yang dijalankan oleh PT. Garuda Indonesia Tbk (Persero), menurut analisa pada Matriks Internal dan Eksternal posisi perusahaan PT. Garuda Indonesia Tbk (Persero) berada pada sel 1 (Growth Strategy), dimana strategi yang dapat dilakukan menurut Rangkuti (2006:42) adalah Strategi Pertumbuhan dengan diversivikasi, dengan cara Strategi diversifikasi merupakan strategi pertumbuhan dimana perusahaan memperluas operasionalnya dengan berpindah ke industri yang berbeda atau menghasilkan produk yang berbeda atau bervariasi, (Diversifikasi terkait /concentric) maupun bidang usaha yang tidak terkait (Diversifikasi tak terkait /konglomerat). 
Kondisi peluang PT. Garuda Indonesia Tbk (Persero), berdasarkan indikator yang menunjukkan Peluang (Opportunity).

1. Kebijakan pemerintah, sebagai perusahaan BUMN PT. Garuda Indonesia Tbk (Persero), mendapatkan fasilitas dan dukungan penuh dari pemerintah.

2. Nilai tukar rupiah stabil, memungkinkan masyarakat Indonesia melakukan perjalan ke luar negeri baik untuk bisnis maupun untuk berlibur.

3. Mengikuti perkembangan teknologi, inovasi dalam perkembangan teknologi yang semakin pesat membuat PT. Garuda Indonesia Tbk (Persero) selalu uptodate dan tidak ketinggalan jaman.

4. Budaya Masyarakat, cinta pada perusahaan dalam negeri akan memberikan keuntungan bagi PT. Garuda Indonesia Tbk (Persero) dalam perkembangan bisnis PT. Garuda Indonesia Tbk (Persero).

Kondisi Ancaman (Threats) bagi PT. Garuda Indonesia Tbk (Persero)

1. Kompetitor dengan modal besar. PT. Garuda Indonesia Tbk (Persero) belum bisa mengimbangi pemodal besar yang menjadikannya kompetitor.

2. Keadaan Ekonomi Indonesia yang tidak stabil akan membuat investor kurang tertarik untuk menanamkan modalnya, hal ini juga berdampak kurang baik PT. Garuda Indonesia Tbk (Persero)

3. Tingkat Inflasi yang terus meningkat berdampak terhadap menurunnkan daya beli masyarakat.

4. Rendahnya peningkatan pendapatan msyarakat akan mengurangi jumlah permintaan tiket perjalanan baik domestik maupun internasional

Kondisi PT. Garuda Indonesia Tbk (Persero) indikator yang menunjukkan Kekuatan (Strength)

1. Fasilitas yang baik dan nyaman, bersih dana aman, membuat penumpang akan memilih dan merekomendasikan PT. Garuda Indonesia Tbk (Persero) pada setiap penerbangan.

2. SDM (Pilot,pramugari,karyawan) memiliki daya tanggap tinggi, dengan keahlian dan daya tanggap yang tinggi Pilot, Pramugari dan karyawan selalu siap melayani pennumpang. 
3. SDM (Pilot,pramugari,karyawan) yang memiliki keperdulian yang tinggi, siap memberikan pelayanan terbaik kepada penumpang akan memberikan kesan tersendiri bagi penumpang

4. SDM (Pilot,pramugari,karyawan) yang handal, tenaga SDM yang professional dan memiliki jam terbang yang tinggi dalam melayani setiap penumpang otomatis akan memberikan nilai plus bagi PT. Garuda Indonesia Tbk (Persero)

Kondisi PT. Garuda Indonesia Tbk (Persero) berdasar indikator yang menunjukkan kelemahan (Weakness)

1. Citra ekslusif, sebagai penerbangan kelas nomor 1 di Indonesia, membuat PT. Garuda Indonesia Tbk (Persero) dianggap penerbangan yang mahal dan eksklusif.

2. Promo khusus kurang, karena citra yang mahal sehingga PT. Garuda Indonesia Tbk (Persero) tidak memiliki penerbangan promo sebanyak dan sebaik pesaingnya

3. Harga tiket PT. Garuda Indonesia Tbk (Persero) tidak terjangkau oleh semua kalangan

4. Teknologi kurang canggih, citra yang mahal belum sebanding dengan inovasi dalam bidang teknologi

\section{Evaluasi}

Berdasarkan analisa Matriks Internal dan Eksternal pada PT. Garuda Indonesia Tbk (Persero) bahwa strategi yang dilakukan oleh PT. Garuda Indonesia Tbk (Persero) adalah Strategi Pertumbuhan dengan upaya diversifikasi artinya PT. Garuda Indonesia Tbk (Persero) dalam posisi pertumbuhan yang baik namun harus terus berinovasi dengan cara menciptakan bisnis baru yang masih berhubungan dengan penerbangan maupun tidak terkait dengan bisnis penerbangan, atau memperbanyak rute penerbangan (menambah rute - rute penerbangan yang baru). 


\section{SIMPULAN DAN SARAN}

Kesimpulan

Berikut beberapa strategi bersaing yang lebih baik bagi PT. Garuda Indonesia Tbk (Persero) saat ini supaya mampu memenangkan persaingan dimasa mendatang, serta bagaimana daya saingnya:

1. Berinovasi dengan cara menambah kemampuan atau skill SDM

2. Menambah jumlah pesawat - pesawat baru

3. Menciptakan penerbangan - penerbangan promo guna menjaring konsumen dari berbagai segmen

4. Berinovasi dengan teknologi yang canggih

\section{Saran}

1. Memanfaatkan kekuatan yang ada hendaknya terus meningkatkan teknologi dan inovasi sarana dan prasarana yang sesuai dengan keinginan penumpang pembelian, mengikuti trend dan tidak terlalu kaku dengan citra eksklusif yang sudah melekat.

2. Meningngkatkan atau menambah rute jumlah penerbangan baru yang produktif dan mengurangi atau menghapus jdwal penerbangan yang tidak produktif.

3. Menambah jumlah penerbangan promo

4. Bekerjasama dengan pihak swasta dalam meningkatkan pelayanan

5. Menjalin kerjasama dengan pesaing dengan menjadikannya sebagai investor

\section{E. DAFTAR PUSTAKA}

Ali, Hasan, 2013, Marketing dan kasus-kasus pilihan, Yogyakarta. CAPS (Center For Academic Publishing Service).

Alma, Buchari, 2012, Manajemen Pemasaran dan Pemasaran Jasa, Penerbit PT. Alfabeta, Bandung.

Amstrong, Gary, dan Philip, Kotler, 2000, Marketing: An Introduction, International Edition, Sixth Edition, Mc graw Hill, New York.

Anshori Yusak. 2005. Analisis Keunggulan Bersaing Melalui Penerapan Knowledge Management dan Knowledge Based-Strategy di Surabaya Plaza Hotel. Jurnal Manajemen Perhotelan, Vol 1. No. 20, pp 39-53

Arikunto, Suharsimi. 2002. Prosedur Penelitian. Jakarta: Rineka Cipta.

Assauri, Sofjan. 2013. Strategic Management Sustainable Competitive Advantage. Jakarta: PT. Raja Grafindo Persada 
Barret, Richard, 2003, Bussiness \& Economic, , Vocational Business : Trainning, Develoving and Motivating People page 51

Budiarti, Tuti .2012. Pengaruh citra merek terhadap pengambilan keputusan pembelian sepeda motor Kawasaki pada PT. Diana Indonesia di Makassar. Makassar : program S1 Fakultas ekonomi dan bisnis Unhas.

Griffin R 2006, Businees 8 th Edition NJ: Prectce hall

Handoko T. Tani. 2013. Manajemen Dan Sumber Daya Manusia. BPFE. Yogyakarta

Keegan, Warren J. 2007. Manajemen Pemasaran Global. Edisi Keenam. Jakarta: PT. Indeks

Kotler dan Keller, 2012 Marketing Management edisi 14, Global Edition. Pearson Prentice Hall.

Malhotra Naresh H. 2010. Marketing Research an Applied Orientation Sixth Edition. England: Person Education Limited 2010.

Moleong, Lexy. 2006. Metodologi Penelitian Kualitatif. Bandung: PT. Remaja Rosda Karya

Payne, Andrian, 2009, The Essence of Service Marketing, Alih Bahasa: Fandy Tjiptono, Edisi Kedua, Penerbit Andi, Yogyakarta.

Peter, J. Paul, Jerry, C., Olson, 2002, Consumer Behavior and Marketing Strategy, Sixth Edition, Mc Grow Hill, New York.

Robbins, Stephen dan Mary Coulter, 2007, Management, 8 Edition, NJ: Prentice hall

RSD Purnomo, Cita Y Serfiani, Iswi Heriyani. 2013. Buku Pintar Investasi Properti. Jakarta: Gramedia Pustaka Utama PT.

Suciningtyas, Wulan, (2012), Pengaruh Brand Awareness, Brand Image, Dan Media Comumunication Terhadap Keputusan Pembelian. Management Analysis Journal. Vol 1 No 1 Agustus 2012.

Sugiyono, 2003, Statistika untuk Penelitian, Cetakan Kelima, Penerbit Alfabeta, Bandung.

Sugiyono. 2012. Metodologi Penelitian Kuantitatif Kualitaif dan $R$ \& D. Cetakan ke17. Bandung: Alfabeta CV.

Suprapto J, Limakrisna Nandan. 2013. Petunjuk Praktis Penelitian IImiah untuk Menyusun Skripsi Tesis dan Disertasi Edisi 3. Jakarta: Mitra Wacana Media.

Surna I Nyoman. 2012. Pedoman Penulisan Karya Ilmiah. Jakarta: Fak. Psikologi Universitas Persada Indonesia-YAI. 